up the narratives of the Lord's Appearances. The English is beautiful and the attitude of mind reverent and spiritual. Here is as fine a specimen of real exposition as one could wish to find. Dr. Swete is open to all truth and is cautious and candid. I cannot go with him in his suggestion that the appearance of Mary and of the other women is one and the same event. But there is very little to which one can refuse to give hearty assent. The numerous Greek notes are in footnotes and are very helpful, but they do not interfere with the popular style of the book. It is refreshing to read so reassuring a book of firm faith after wandering through Dr. Kirsopp Lake's doubts about the Resurrection of Jesus. Dr. Swete's book will do one good.

A. T. Robertson.

\title{
Jesus.
}

By Arno Neuman. Translated by M. A. Canney, London, England, A. \& C. Black. 1906. Pages 180.

Dr. P. W. Schmiedel has a somewhat extended introduction to the work of his pupil, Dr. Neumann. In fact it is Schmiedel all through, only not quite so offensively put. Dr. Neumann does say that the birth of Jesus is the most important date in history, though he considers and treats Jesus only as a man. These two writers take themselves seriously because they claim to be able to prove that Jesus really existed. They do to their own satisfaction, but I have heard of no converts by their arguments from among the small number who consider Jesus as purely mythical. The trouble is that what they prove is a mere barren ideality.

A. T. Robertson.

\section{Luke the Physician, the Author of the Third Gospel and the Acts of the Apostles.}

By Adolph Harnack. Tran lated by Rev. J. R. Wilkinson, M. A., New York, G. P. Putnam's Sons. London, Williams \& Norgate. 1907. Pages 231.

This volume is well worthy to belong to the Crown Theological Library. All that Harnack writes is interesting and the English version puts this notable book in the reach of all who care to have it. The original Iukas der Artz was reviewed in this journal and hence a shorter mention will now suffice. 